LAW AND CATASTROPHE 
The Amherst Series in Law, Jurisprudence, and Social Thought EDITED BY

Austin Sarat, Lawrence Douglas, and Martha Merrill Umphrey 


\section{Law and Catastrophe}

Edited by

AUSTIN SARAT

LAWRENCE DOUGLAS

MARTHA MERRILL UMPHREY

STANFORD UNIVERSITY PRESS

Stanford, California, 2007 


\section{Stanford University Press Stanford, California (C) 2007 by the Board of Trustees of the Leland Stanford Junior University All rights reserved}

No part of this book may be reproduced or transmitted in any form or by any means, electronic or mechanical, including photocopying and recording, or in any information storage or retrieval system without the prior written permission of Stanford University Press.

Library of Congress Cataloging-in-Publication Data

Law and catastrophe / edited by Austin Sarat, Lawrence Douglas, Martha Merrill Umphrey.

p. cm.-(The Amherst series in law, jurisprudence, and social thought) Includes index.

ISBN 978-0-8047-5683-9 (cloth : alk. paper)

1. Disasters - Law and legislation. 2. Disaster relief-Law and legislation. 3. Industrial accidents-Law and legislation. 4. Social responsibility of business. 5. Disasters. I. Sarat, Austin. II. Douglas, Lawrence. III. Umphrey, Martha Merrill.

K1980.L39 2007

$344.05^{\prime} 34-\mathrm{dc} 22$ 
To my son Ben (A.S.) 
